\title{
CULTURAL AND INTERCULTURAL ISSUES IN GLORIA ANZALDÚA'S POETRY
}

\author{
CĂTĂLIN NICOLAU \\ Alexandru Ioan Cuza University of Iaşi, Iaşi, Romania
}

\begin{abstract}
In this paper I aim at looking at some of the themes that Gloria Anzaldúa approaches in her poetry. As all the authors representing and writing on behalf of the American ethnic minorities, she is especially concerned with defining the cultural identity of her people; thus, she focuses on the cultural profile of the American Chicanos and, at the same time, on the relationship of her people with the whites.

The poetess is not only interested in exploring her ethnic identity, she is also preoccupied with feminism; actually, she aims at articulating the figure of the New Mestiza, the Chicana woman that fights for liberation from both the whites' oppression and that of men.

One of the recurrent concepts in Gloria Anzaldúa's poetry is that of the border, which is explored from a(n) (inter)cultural perspective and which is used for defining the identity of the American Chicanos.
\end{abstract}

Keywords: border, border crossing, feminism, hybridity, melting pot, Mexican-Americans, Nepantla, postcolonialism, salad bowl

\section{Introduction}

In this paper, as the title suggests, I aim at looking at Gloria Anzaldúa's poetry; more specifically, I am especially interested in the way in which the Mexican writer deals with a few issues, such as the identity of the Mexican Americans (and I refer here to the ethnic, the social, and the cultural identities of the people living near the Mexican-American border). Another topic that I will be focusing on is Gloria's feminism, which is very much connected to another theme: that of the poetess' lesbian identity. I especially focus on the chapters of poetry that make up the second part of Gloria Anzaldúa's famous book Borderlands/ La Frontera. I have chosen the poetry section as I have found it more interesting 
and more challenging to try to study and decode her ideas articulated in a poetic form rather than just take them out of her prose fiction or her interviews and merely rephrase them.

As we all know, America is a multiethnic, multicultural nation, made up of people originating from all the regions of the world. Maybe the most famous metaphor that is used to describe this cosmopolitan specificity is melting pot. The phrase melting pot underlines the multicultural character of this nation: the fact that the ethnic groups that make up America bring together their own cultural heritage and "melt" them into a homogeneous whole which is the American culture; this traditional approach suggests that these groups lose their identity as they become Americans (they "melt" as they become part of a homogeneous mass). It is important to understand that this metaphor brings up a holistic perspective; it focuses on the whole of the American culture.

Salad bowl is a more recent phrase, maybe less known but equally suggestive. It looks at the American culture in a slightly different way: this second metaphor no longer focuses on America as a whole, but on its component elements; if we picture the image of a salad bowl we notice that the constituent elements, i.e., the ingredients, remain visible while they contribute to the making of the entire dish. Similarly, the latter phrase suggests not only that America is made up of several ethnic groups, but that each of these groups has its own cultural identity and this identity is not completely melting into the American mainstream culture, but still preserves some of its original features. This way of looking at the American culture is illustrated in the literature of its ethnic minorities: African-American, Jewish-American, Chinese-American, Native American, and Mexican-American. The representatives of these ethnic groups write literary pieces in which they try to express their cultural heritage and identity, they attempt at conveying the specificity of their peoples' cultural profiles.

Gloria Anzaldúa is a representative of the Mexican-Americans and, as I have already mentioned, the second part of her Borderlands is devoted to poetry (the first part is entitled Atraversando Fronteras/ Crossing Borders and it contains a number of prose pieces that deal with various historical and cultural aspects meant to define the Chicano people, the people living in the American frontier region). The second part is devoted to poetry, a type of poetry that continues to some extent the themes that have been approached in the prose woks. The poems are concerned primarily with various aspects regarding the cultural identity of the American Chicanos. Who are the Chicanos? The Chicanos are a group of people of Mexican origin living in an area that once belonged to the Mexican state but was taken away by the United States in 1848 . The poetess is interested in the consequences undergone by these people on the cultural plane after their territory (the former northern Mexico) was annexed to the U.S. After the conquest of the southern Texas the Mexicans living in that 
region were exposed to the white American culture, so, according to Anzaldúa, they became culturally hybrid: they had access to both their own culture and that of their colonizers (the Mexican and the Anglo-American ones). Thus, their universe is now shaped by two ways of looking at, and, consequently, of understanding, the world.

\section{The Border}

A central concept that Gloria focuses on is that of the border, which is redefined in both her literary and non-fiction texts. It is no longer considered politically, as we might expect; instead, it is looked at from a cultural perspective. By border we usually and traditionally understand something that separates states, nations, cultures, something impermeable; however, in our contemporary world, the Mexican poetess argues, it gradually becomes something that can be transgressed with ease, especially due to the great development of the Internet. ${ }^{1}$ A similar phenomenon is seen (and analysed) with respect to the Chicanos. Their living near the border enables them to have access to more than one culture. The idea of border-crossing is dealt with nearly obsessively in Anzaldúa's works. However, the author goes beyond this as she also mentions the Native-American (Indian) roots of the Chicanos, which, she argues, are still present and manifest in her people's cultural profile. So, the Chicano civilization actually represents the intersection of three cultures: Indian, Mexican, and American.

\section{Cultural Identity}

This topic of cultural identity is illustrated in such poems as Cihuatlyoth, Woman Alone, Creature of Darkness, or To Live in the Borderlands Means You. Creature of Darkness, for instance, points to the speaker's inner duality; inside her there two antinomic tendencies: one that urges her to come to light (and to make her voice heard) and another one oriented towards preserving the current state of things (corresponding to the conservative traditional view).

The poem To Live in the Borderlands Means You aims at defining the condition of Border people. A Border person is considered a "forerunner of a new race ... a new gender"; (s)he illustrates a cultural typology that incorporates features of two or more civilizations. The cultural profile of Borderland people is metaphorically defined as a sort of battleground in which several national identities come into contact and manifest themselves simultaneously. Sometimes

\footnotetext{
${ }^{1}$ The Internet leads to the annihilation of traditional borders and, generally, of physical distance: it allows people to interact and communicate over great distances just as easily as though they were in the same town or even in the same building.
} 
they clash, so contradictory manifestations may appear: "you are at home, a stranger." " This line clearly points to the stage of Nepantla or border crossing. Nepantla is a Nahuatl word designating the space between two bodies of water; here, it refers to the space between two worlds, a space whose inhabitants are influenced by two (or more) cultural identities. In order to survive these border people must live sin fronteras, i.e., without borders. The poetess pleads for an attitude of openness towards both (or all the) cultures that intersect in a certain area. For the Border people the notion of border loses its traditional significance of "barrier."

Nepantla is considered a very uncomfortable stage to be in; it also implies a way of looking at the world, of understanding it, and of writing about it. It is a chaotic way of experiencing the world: one gets all sorts of disconnected ideas and impressions (from the different worlds one belongs to) which one is supposed to organize and make some sense of:

[Nepantla] is one of the stages of writing, the stage where you have all these ideas, all these images, sentences and paragraphs, and where you are trying to make them into one piece, a story, plot, or whatever. It is all very chaotic, so you feel like you are living in the midst of chaos... The art of composition always means pulling off fragmented pieces and putting them together into a whole that makes sense. (Ikas 14)

Closely related to the specificity of these Border people is the idea of "hybridity", which is, maybe, the most striking feature of Gloria's texts and is to be applied both to their linguistic form and their themes. It is not to be understood as a mere stylistic device, but, especially, as a cultural attribute that essentially defines the condition of border people (and of Gloria herself).

\section{Hybridity}

Hybridity is clearly detectable on the linguistic level: most of her texts are "multilingual" in the sense that they contain words from several languages. This is not accidental, as Gloria Anzaldúa is a multilingual writer (she claims so in her interviews) and fully aware of her multi-ethnic identity. Gloria admits that in her texts she mainly uses three languages: English, Spanish (in three varieties), and Navajo, of which the last one is that which she claims to prefer (11). Her choice of using several languages in the same text is not a mere stylistic option, but it accounts for her revolt against the old "white" way of placing individuals

\footnotetext{
${ }^{2}$ To these Borderland people, a certain place may be felt as home up to a certain point, but beyond it, it appears as if it were seen through the eyes of a stranger.
} 
into some clear-cut categories. But this traditional way of understanding things is no longer applicable to Gloria's Border people and Border areas as here boundaries are no longer relevant: ethnic and cultural elements often overlap and intermingle. Breaking the linguistic boundaries is highly significant as it suggests the poetess' firm decision to no longer accept "white" labels, such as that of a third-world inhabitant.

Gloria Anzaldúa is a Nepantlera, that is, a Border person. As such, she rejects the traditional (too) rigidly distinguished categories. She cannot be characterized by the usual terms used by the whites: Chicano, feminist, lesbian, etc. Instead, "she maintains multiple allegiances and locates herself, simultaneously, in multiple worlds" (Keating 3). It is only the "white" rigid labels that put her in one category or another; according to her, it is as if she were on some thresholds that allowed her to "engage in multiple dialogues simultaneously. She rejects the need for unitary identities and exclusive, single-issue alliances, and replaces naturalized concepts of ethnicity, gender, sexuality, or other systems of difference with more openly relational forms” (3).

This hybridity is also characteristic of her style in terms of the genres that she approaches: her work is "a complex blending of cultural and personal biography with memoir, fiction, history, myth, theory, and other forms of story-telling” (6). Gloria prefers using a variety of genres; she is not confined to just one, because she wants to make her texts intelligible to all her readers, irrespective of their age, status, or education (Ikas 12). In her interviews, Gloria Anzaldúa refers to two interesting concepts: autohistoria and autohistoria-teoría. Although she has no texts specifically focused on defining these notions, one can try to understand what she meant by them from the way in which they are used. Thus, according to Ana Louise Keating, Gloria's autohistoria focuses on one's life story, which sometimes takes a fictional form, as it is the case with the Prieta series (Keating 6). The other concept, autohistoria-teoría, unlike the previous one, also contains some theoretical elements as well. Both genres enable Gloria to try to revise and re-think her experience in terms of the cultural and intercultural phenomena that she focuses on in her other texts.

The identity of the Chicanos also involves their social condition and ways of life and the way in which they relate to the Whites. The hard life of the Chicano people and the oppression to which they are subject appear in such poems as White-wing Season, Horse, Cultures, or We Call Them Greasers. White-wing Season, for instance, focuses on the poverty that characterizes the Mexicans' living. We are shown a farm woman who is forced to accept money from the American "white men" in order to allow them to shoot white-winged doves on her land. She has no other choice but to accept this killing so as to be able to feed her family. So, the social condition of the Chicanos is by no means a happy one, as they are forced to accept painful compromises to the whites. 
We Call Them Greasers is also interesting from a technical point of view because the poetess adopts here the perspective of the oppressor and narrates from the viewpoint of the white Americans' leader. The whites come to banish the Chicanos from the land where they work, claiming that they owe taxes. The Mexicans who refuse to leave are subject to tremendous tortures. The narrator relates the rape of a woman in front of her husband who had been tied to a tree, upon which both of them are killed.

\section{The New Mestiza}

Another main issue in Gloria Anzaldúa's writing is feminism. In her poems she tries to articulate the figure of what she calls the New Mestiza. The New Mestiza is the Chicana woman who longs and fights for liberation both from the whites' oppression and from that of men. So, she fights not only for the rights of her people (ethnically speaking), but also for those of women. The identity of the Chicana figure was shaped in her mind during the poetess' childhood and teenage experience "on a ranch settlement known as Jesus María in the Valley of South Texas and then in a little town called Hargill” (Bădulescu 173).

The feminist attitude is visible in such poems as Cervicide, El sonavabitche, sus plumas el viento (Give Wind to Her Feathers), or Cihuatlyotl, Woman Alone. In El sonavabitche we are shown how the mojados (illegal immigrants from Mexico) are exploited: they are forced to work fifteen hours a day, from dawn to dark, and they are transported like animals in inhuman conditions. However, the figure of the New Mestiza is shaped here in the person of the Chicana woman who has the guts to claim the money she has worked for and threaten the field owner (the "sonavabitche") that she will expose his using illegal immigrants.

Cervicide is a poem about a girl named Prieta who has a small fawn as her pet. She and her brothers found the fawn when it had only been few hours old and have been taking care of it ever since. Hearing the game warden coming, she realizes that she has to kill her pet because if she were caught in the possession of a deer, her father would be imprisoned. As her mother does not have the courage nor the strength to kill the fawn, Prieta is supposed to do it with a hammer and then to bury the corpse. The story may be interpreted from a feminist angle. Since in the archetypal symbology the Self appears represented as a deer for women, the fawn may be considered the feminine self that needs to be repressed in a male-dominated culture.

The poem entitled Interface (which belongs to the chapter Crossers and Other Misfits) apparently focuses on the theme of lesbian sexuality but this is only a pretext for approaching a larger intercultural issue. The poetess imagines here that she has a relationship with a female alien whom/ which she names Leyla. In the course of this relationship she tries to teach her how things are 
going in our world and Leyla change from the way she was at the beginning. She adopts a lot from what it means to be human, but in the end the poetess still considers her an alien. Despite its science-fiction appearance, the poem may be discussed in cultural terms and from this angle we may say that it illustrates the concept of Napantla (see above). Thus, it describes the transition phase that one passes through when one adopts (or is in the process of adopting) a new cultural identity. It is a frustrating, an uncomfortable state as the individual is in the process of change: (s)he has not yet left behind the old identity and (s)he has not adopted the new one either. The individual is on the point of crossing a border between two cultures, which makes him/ her fully belong to neither of the two. Leyla illustrates precisely this stage of Nepantla as she/ it is not $100 \%$ human and she/ it has not yet completely given up her alien nature.

With respect to the identity of the people involved in a process of colonization, Anzaldúa believes that out of the interaction between the two (the colonizer and the colonized), there emerges a sort of cultural overlapping, in the sense that either party gets "contaminated" with various features of the other party:

However, what is happening, after years of colonization, is that all the divides disappear a little bit because the colonizer, in his or her interaction with the colonized, takes on a lot of the attributes. And, of course, the person who is colonizing leaks into our stuff. So we are neither one nor the other; we are really both. There is not a pure other; there is not a pure subject and not a pure object: We are implicated in each other's lives. (Ikas 20-21)

As shown earlier, Gloria Anzaldúa was always preoccupied with various issues related to the act of writing and, according to her, this process always involves an attempt at challenging the traditional conventions: "And here I am pushing at the laws and rules of the genres ... So I have to struggle between how many of these rules I can break and how I can still have readers read the book without getting frustrated" (7).

According to her, a writer should start from the traditional conventions but should ponder how many of them are to be preserved and applied and how many of them (s)he should challenge. The same attitude, she argues, is to be adopted by the Chicanos as well: "It is the same kind of struggle mestizas have living at the borders, living in the borderlands. How much do they assimilate to the white culture, and how much do we resist and risk becoming isolated in the culture and ghettoized? This issue applies to everything”(7). 


\section{Conclusions}

Gloria Anzaldúa is a postcolonial writer perfectly integrated into her postmodernist generation. Her texts not only approach issues pertaining to various cultural and intercultural contemporary phenomena, but they also pose interesting and challenging difficulties to their readers. Technically speaking, it is worth noticing that many of her texts do not have one (thematic) centre: the topics that the poetess enlarges upon are not treated separately; instead, they are most often combined. ${ }^{3}$ This quality of her work definitely accounts for Gloria's literary skill, as a talented writer is, among other things, capable of approaching several issues at the same time. He/ She is able to focus on more than one theme at a time and, thus, to create and develop several layers of meaning in the same text.

\section{References}

Anzaldúa, Gloria. Borderlands/ La Frontera. San Francisco: Aunt Lute Books, 2012. Print.

Bădulescu, Dana. PoMo Mosaics. Iaşi: Casa Editorială Demiurg, 2004. Print.

Ikas, Karin Rosa. Chicana Ways: Conversations with Ten Chicana Writers. Reno: University of Nevada Press, 2001. Print.

Keating, Ana Louise. Entre Mundos/ Among Worlds: New Perspectives on Gloria E. Anzaldúa, New York: Palgrave Macmillan, 2005. Print.

\section{BIONOTE}

Cătălin Nicolau, $\mathrm{PhD}$, is currently teaching English grammar and phonetics at the Faculty of Letters, "Alexandru Ioan Cuza" University of Iaşi. So far, his research preoccupations have ranged through general linguistics, literary theory and criticism and the philosophy of science. His interest in these apparently disparate fields is fueled by his conviction that scientific theories in both natural sciences and humanistic disciplines have a common ground: they are shaped by the same vision and understanding of reality; it is this underlying worldview that a researcher has to be aware of for a proper grasp of any topic he/ she may want to approach.

E-mail: catalin_george2001@yahoo.com

\footnotetext{
${ }^{3}$ See the references to the poems Cervicide and Interface.
} 